\title{
FAKTOR-FAKTOR YANG BERHUBUNGAN DENGAN KEPATUHAN BIDAN ALUMNI POLITEKNIK BHAKTI ASIH PURWAKARTA TERHADAP PELAYANAN ANTENATAL CARE SESUAI STANDAR
}

\author{
Dita Humaeroh \\ Nama Institusi dan Alamat Institusi Lengkap, Negara \\ Email: humaerohdita@gmail.com
}

Received: 29-04-2021

Revised: 10-05-2021

Accepted: 20-05-2021

\begin{abstract}
Compliance midwife implement service standards determine the quality of service. The compliance level of the Midwifery Alumni Polytechnic Bhakti Asih Purwakarta in antenatal care services according to standards was very low at 52\%. This study aims to determine factors of Education, Training, Supervision and Motivation associated with the Midwife's influence in ANC services according to standards. This research is important because midwife compliance in antenatal care services according to standards is a standard that must be carried out by midwife in providing services to antenatal care patients. This research uses quantitative methods with cross sectional design. The subject of research was Midwifery Alumni Polytechnic Bhakti Asih Purwakarta force X and XI as much as 160who carried out Antenatal Care services according to the standard. The sample of this research was the Alumni Midwife who were taken by random sampling and the total sample of 114 people. The results showed a significant relationship ( $p$-value $<0.05$ ) between Education (P-Value 0.018), Training (P-Value 0.029) and Motivation $(P$-Value 0,000) with the Compliance of the Midwife Alumni Polytechnic Bhakti Asih Purwakarta in ANC services according to the standard. While the unrelated factor is Supervision (P-Value 0.416). It is recommended to the Midwife of Polytechnic Bhakti Asih Purwakarta to be obedient in applying antenatal care service standards according to the standards, and improve supervision of the head of the Puskesmas / Midwife Coordinator / Midwife of Independent Practice to further improve midwife compliance, and conduct training related to midwife competencies.
\end{abstract}

Keywords: Midwife Compliance; Education; Training; Motivation;supervision.

\footnotetext{
Abstrak

Kepatuhan bidan menerapkan standar pelayanan menentukan kualitas pelayanan. Tingkat kepatuhan Bidan alumni Politeknik Bhakti Asih Purwakarta dalam pelayanan
} 
antenatal care sesuai standar sangat rendah sebesar $52 \%$. Penelitian ini bertujuan untuk mengetahui faktor Pendidikan, Pelatihan, Supervisi dan Motivasi yang berhubungan dengan kepatuhan Bidan dalam pelayanan ANC sesuai standar. Penelitian ini penting dilakukan karena kepatuhan Bidan dalam pelayanan antenatal care sesuai standar merupakan standar yang harus dilaksanakan oleh bidan dalam memberikan pelayanan kepada pasien antenatal care. Penelitian ini menggunakan metode kuantitatif dengan rancangan cross sectional. Populasi penelitian adalah Bidan Alumni Politeknik Bhakti Asih Purwakarta angkatan X dan XI sebanyak 160 orang yang melakukan pelayanan Antenatal Care sesuai standar. Sample penelitian ini adalah Bidan Alumni yang di ambil dengan random sampling dan jumlah sampel sebanyak 114 orang. Hasil menunjukan adanya hubungan yang signifikan ( $p$-value $<0,05)$ antara Pendidikan (P-Value 0,018), Pelatihan $(P$-Value 0,029$)$ dan Motivasi $(P$-Value 0,000$)$ dengan Kepatuhan Bidan Alumni Politeknik Bhakti Asih Purwakarta dalam pelayanan ANC sesuai standar. Sedangkan faktor yang tidak berhubungan yaitu Supervisi (P-Value 0,416). Disarankan kepada Bidan Alumni Politeknik Bhakti Asih Purwakarta untuk patuh dalam menerapkan standar pelayanan antenatal care sesuai standar, dan memperbaiki supervisi dari kepala puskesmas/Bidan Koordinator/Bidan Praktek Mandiri untuk lebih meningkatkan kepatuhan bidan, serta mengadakan pelatihan berkaitan dengan kompetensi bidan.

Kata kunci: Kepatuhan Bidan; Pendidikan; Latihan; Motivasi; Pengawasan.

Coresponden Author : Dita Humaeroh

Email : humaerohdita@gmail.com

CC BY ND

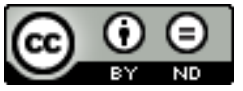

\section{PENDAHULUAN}

Kepatuhan bidan dalam menerapkan standar pelayanan antenatal yang merupakan indikator penting dalam standar pelayanan bagi kesehatan ibu dan anak mempunyai dampak terhadap pencegahan terhadap komplikasi-komplikasi yang terjadi selama kehamilan. Oleh karena itu sangat dibutuhkan pengawasan antenatal care secara optimal kepada seorang ibu yang sudah terdiagnosa kehamilannya agar dapat terdeteksi secara dini masalah yang ada dalam kehamilannya sehingga komplikasi lebih lanjut tidak terjadi (WHO, 2008). Menurut Penelitian yang dilakukan oleh (Gunawan et al., 1990) kepatuhan bidan yang di observasi akan berdampak kepada kualitas pelayanan ANC sesuai dengan standar.

Menurut penelitian (Prual et al., 2000) di Nigeria kepatuhan bidan dalam pelayanan antenatal care adalah sebagai alat untuk mencegah dan memprediksi komplikasi obstetri selama kehamilan. Kepatuhan bidan dalam standar pelayanan antenatal care khususnya 
pemeriksaan protein urin dan hemoglobin sangat diperlukan karena untuk mencegah komplikasi pada ibu hamil dan pada saat persalinan menurut penelitian (Rahayu, 2011).

Kepatuhan petugas yang rendah dalam menerapkan standar dapat dilihat dari beberapa penelitian berikut, di Indonesia dari hasil penelitian yang dilakukan oleh (Afriani, 2012) di Kota Padang Sidampuan ditemukan sebagian Bidan yang patuh dalam pelayanan antenatal care sesuai standar. Sedangkan menurut penelitian (Nurbaeti, 2000) di kabupaten Bekasi masih banyak ditemukan bidan yang kepatuhannya kurang dalam menerapkan standar pelayanan antenatal dari seluruh bidan di enam puskesmas yang diteliti. Menurut penelitian (Gunawan et al., 1990) menyebutkan bahwa kepatuhan petugas yang di awasi dapat meningkatkan kualitas pelayanan antenatal care sesuai standar yang ditentukan.

Kepatuhan petugas menerapkan standar pelayanan antenatal care 14T bisa dipengaruhi oleh faktor-faktor diantaranya supervisi, motivasi, pendidikan dan Pelatihan. Menurut penelitian (Setyowati, 2009)untuk meningkatkan kepatuhan petugas kesehatan harus dilakukan pengawasan atau supervisi secara berkala. Dari penelitian di India oleh (Sharma et al., 2011) kepatuhan yang rendah disebabkan oleh kurangnya motivasi, pendidikan dan pelatihan dari petugas kesehatan.

Politeknik Bhakti Asih Purwakarta telah meluluskan lebih dari 1000 Bidan dari tahun 2005, berdasarkan study pendahuluan hampir 52\% alumni Politeknik Bhakti Asih Purwakarta Prodi Kebidanan tidak patuh dalam melakukan pelayanan antenatal sesuai standar.

\section{METODE PENELITIAN}

Penelitian ini merupakan penelitian dengan pendekatan kuantitatif, yang menggunakan metode pendekatan Cross sectional dimana penelitian ini untuk mempelajari dinamika korelasi antara faktor-faktor resiko dengan efek, dengan pendekatan, observasi atau pengumpulan data sekaligus pada suatu saat (point time approach), metode dan pendekatan dalam penelitian ini untuk mengatahui serta menjelaskan hal-hal apa saja yang menjadi faktor-faktor yang berhubungan dengan kepatuhan bidan dalam memberikan perlayanan antenatal care sesuai standar.

Penelitian ini di lakukan di Purwakarta pada tahun 2020. Populasi penelitian adalah Bidan Alumni Politeknik Bhakti Asih Purwakarta angkatan X dan XI sebanyak 160 yang melakukan pelayanan Antenatal Care sesuai standar. Sample penelitian ini adalah Bidan Alumni yang di ambil dengan random sampling dan jumlah sampel sebanyak 114 orang. Pengumpulan data dilakukan dengan cara berkoordinasi dengan alumni Politeknik Bhakti Asih Purwakarta yaitu membagikan kuesioner dan lembar observasi ke alumni angkatan $\mathrm{X}$ dan XI. Pengolahan data diolah dengan batuan komputer yaitu melalui beberapa tahapan mulai dari pengodean, penyuntingan, pemasukan data, dan pengoreksian data. Analisa data dilakukan secara bertahap mulai dari analisa univariat dan analisa bivariat dengan menggunakan Chi-Square.

\section{HASIL DAN PEMBAHASAN}

Tabel 1.1 Distribusi frekuensi kepatuhan Alumni Bidan Politeknik Bhakti Asih Purwakarta angkatan X dan XI terhadap pelayanan ANC sesuai standar 


\begin{tabular}{|l|c|c|}
\hline \multirow{2}{*}{ Variabel } & Frekuensi & Presentase \\
\cline { 2 - 3 } & $\mathbf{N}$ & $\mathbf{( \% )}$ \\
\hline Patuh & 49 & 34 \\
Ya & 65 & 57 \\
Tidak & & \\
\hline Pendidikan & 102 & 89.5 \\
Diploma III & 12 & 10.5 \\
D4/Sarjana & & \\
Kebidanan & & \\
\hline Pelatihan & & 38.6 \\
Pernah & 44 & 61.4 \\
Tidak Pernah & 70 & \\
\hline Supervisi & & 26.3 \\
Ya & 30 & 73.7 \\
Tidak & 84 & \\
\hline Motivasi & & 46.5 \\
Rendah & 53 & 53.5 \\
Tinggi & 61 & \\
\hline
\end{tabular}

Berdasarkan Tabel 1.1 Bidan alumni Politeknik Bhakti Asih Purwakarta angkatan $X$ dan XI yang tidak patuh terhadap pelayanan Antenatal Care sesuai standar sebanyak 63 responden $(57 \%)$. Distribusi pendidikan paling banyak yaitu Diploma III kebidanan sebanyak 102 Responden (89.5\%) sedangkan D4/S1 Kebidanan sebanyak 12 responden (10.5\%). Distribusi pelatihan paling banyak tidak pernah mengikuti pelatihan sebanyak 70 responden $(61.4 \%)$ dan yang pernah pelatihan sebanyak 44 responden $(38.6 \%)$. Distribusi berdasarkan Supervisi paling banyak tidak dilakukan supervisi sebanyak 84 responden (73.7\%) dan yang dilakukan supervisi sebanyak 30 responden (26.7\%). Dan untuk distribusi berdasarkan motivasi paling banyak motivasi tinggi sebanyak 61 responden $(53.3 \%)$.

Tabel 1.2 Distribusi pendidikan dengan kepatuhan Bidan Alumni Politeknik Bhakti Asih Purwakarta angkatan X dan XII terhadap pelayanan antenatal care sesuai standar

\begin{tabular}{|c|c|c|c|c|c|}
\hline \multirow[t]{3}{*}{ Variabel } & \multicolumn{4}{|c|}{ Kepatuhan } & \multirow{3}{*}{$P$ Value } \\
\hline & \multicolumn{2}{|c|}{ Patuh } & \multicolumn{2}{|c|}{ Tidak patuh } & \\
\hline & $\mathbf{N}$ & $\%$ & $\mathbf{N}$ & $\%$ & \\
\hline Pendidi & & & & & \\
\hline DIII & 40 & 81.6 & 9 & 18.4 & 0.028 \\
\hline D4/S1 & 63 & 95.4 & 3 & 4.6 & \\
\hline
\end{tabular}

Hasil analisis menunjukan bahwa ada hubungan antara pendidikan dengan kepatuhan dalam pelayanan antenatal care sesuai standar dengan P-value 0.028. responden yang pendidikan D4/S1 (95.4\%) lebih banyak di bandingkan dengan Diploma III (81.6\%). Odds Ratio sebesar 0.2 artinya bidan dengan pendidikan D4/S1 Kebidanan mempunyai peluang 0.2 kali lebih besar untuk patuh terhadap pelayanan antenatal care sesuai standar dibandingkan dengan bidan pendidikan Diploma III.

Pendidikan adalah tingkat pengetahuan format tertinggi yang diperoleh sesuai dengan ijazah terakhir di sekolah (Notoatmodjo, 2012) Pendidikan seseorang sangat berperan dalam proses terbentuknya perilaku kepatuhan dalam mematuhi peraturan. Makin tinggi tingkat pendidikan formal yang diperoleh, akan makin mudah menerima pengetahuan baru dan akan semakin mudah pula merubah perilakunya dalam memetuhi peraturan yang ditetapkan. 
Hasil penelitian menunjukan bahwa ada hubungan antara pendidikan bidan dengan kepatuhan terhadap pelayanan antenatal care sesuai standar. Hal ini sesuai dengan menyatakan bahwa tingkat pendidikan memiliki hubungan dengan kepatuhan para tenaga ksehatan dalam melakukan cuci tangan sebelum dan sesudah melakukan tindakan terhadap pasien.

Tabel 1.3 Distribusi Pelatihan dengan kepatuhan Bidan Alumni Politeknik Bhakti Asih Purwakarta angkatan X dan XI terhadap pelayanan antenatal care sesuai standar

\begin{tabular}{|c|c|c|c|c|c|}
\hline \multirow[t]{3}{*}{ Variabel } & \multicolumn{4}{|c|}{ Kepatuhan } & \multirow{3}{*}{$\begin{array}{c}P \\
\text { Value }\end{array}$} \\
\hline & \multicolumn{2}{|c|}{ Patuh } & \multicolumn{2}{|c|}{$\begin{array}{l}\text { Tidak } \\
\text { patuh }\end{array}$} & \\
\hline & $\mathbf{N}$ & $\%$ & $\mathbf{N}$ & $\%$ & \\
\hline Pelatihan & & & & & 0.034 \\
\hline Pernah & 25 & 52 & 24 & 49 & \\
\hline Tidak pernah & 20 & 30,8 & 45 & 69.2 & \\
\hline
\end{tabular}

Hasil analisis menunjukan bahwa ada hubungan antara pelatihan dengan kepatuhan Dalam pelayanan antenatal care sesuai standar dengan $P$-value 0,034 . Responden yang pernah mengikuti pelatihan $(52 \%)$ dan tidak pernah pelatihan $(30,8 \%)$. Odds Ratio sebesar 2,3 artinya bidan pernah mengikuti pelatihan mempunyai peluang 2,3 kali lebih besar untuk patuh terhadap pelayanan antenatal care sesuai standar dibandingan dengan bidan yang tidak pernah pelatihan.

Pelatihan adalah suatu bentuk proses pendidikan dengan memperoleh pengalaman belajar. Pelatihan dapat meningkatkan ketaan terhadap prosedur dan mengembangkan sumber daya manusia untuk lebih berkembang. Tujuan pelatihan adalah untuk mebantu tenaga kesehatan memperbaiki keterampilan guna meningkatkan kepatuhan terhadap pelayanan sesuai standar sehingga dapat memberikan pelayanan yang profesional dan berkualitas.

Hasil penelitian menunjukan adanya hubungan pelatihan dengan kepatuhan terhadap pelayanan antental care sesuai standar, hal ini sejalan dengan penelitian (Afriani, 2012). Menurut (Bukhari, 2011) pelatihan sangat dibutuhkan untuk

\begin{tabular}{|c|c|c|c|c|c|}
\hline \multirow[t]{3}{*}{ Variabel } & \multicolumn{4}{|c|}{ Kepatuhan } & \multirow{3}{*}{$\begin{array}{c}P \\
\text { Value }\end{array}$} \\
\hline & \multicolumn{2}{|c|}{ Patuh } & \multicolumn{2}{|c|}{$\begin{array}{c}\text { Tidak } \\
\text { patuh }\end{array}$} & \\
\hline & $\mathbf{N}$ & $\%$ & $\mathbf{N}$ & $\%$ & \\
\hline Motivasi & & & & & 0.000 \\
\hline Tinggi & 33 & 67.3 & 16 & 32.7 & \\
\hline Rendah & 20 & 30.8 & 45 & 69.2 & \\
\hline
\end{tabular}

meningkatkan kepatuhan petugas terhadap standar pengendalian infeksi di Rumah Sakit. Tabel 1.4 Distribusi Supervisi dengan kepatuhan Bidan Alumni Politeknik Bhakti Asih Purwakarta angkatan X dan XI terhadap pelayanan antenatal care sesuai standar

\begin{tabular}{|c|c|c|c|c|c|}
\hline \multirow[t]{3}{*}{ Variabel } & \multicolumn{4}{|c|}{ Kepatuhan } & \multirow{3}{*}{$\begin{array}{c}P \\
\text { Value }\end{array}$} \\
\hline & \multicolumn{2}{|c|}{ Patuh } & \multicolumn{2}{|c|}{$\begin{array}{l}\text { Tidak } \\
\text { patuh }\end{array}$} & \\
\hline & $\mathbf{N}$ & $\%$ & $\mathbf{N}$ & $\%$ & \\
\hline Supervisi & & & & & 0.520 \\
\hline $\mathrm{Ya}$ & 11 & 22.4 & 38 & 77.6 & \\
\hline Tidak & 19 & 29.2 & 46 & 70.8 & \\
\hline
\end{tabular}


Hasil analisis menunjukkan bahwa tidak ada hubungan antara pelatihan dengan kepatuhan Dalam pelayanan antenatal care sesuai standar dengan P-value 0,520. Responden yang pernah dilakukan supervisi $(22.4 \%)$ dan tidak pernah disupervisi (29.2\%). Odds Ratio sebesar 0.7 artinya bidan yang pernah di supervisi mempunyai peluang 0.7 kali lebih besar untuk patuh terhadap pelayanan antenatal care sesuai standar dibandingan dengan bidan yang tidak pernah disupervisi.

Supervisi adalah proses pengendalian untuk tindak lanjut dari implementasi kegiatan untuk memastikan agar pelaksanaan tugas sesuai dengan rencana atau sesuai standar yang telah ditetapkan. Menurut Heidjarahman dan Suar disebutkan dalam pengawasan adalah mengamati, memberikan saran dan masukan serta membandingkan pelaksanaan dengan rencana dan mengoreksi nya apabila terjadi penyimpangan atau kalau perlu menyesuaikan kembali rencana yang telah di buat.

Hasil penelitian menunjukkan tidak ada hubungan antara supervisi dengan kepatuhan bidan. Hal ini tidak sesuai dengan penelitian yang dilakukan oleh (Afriani, 2012) yang menyatakan bahwa supervisi memunyai hubungan yang sugnifikan dengan kepatuhan bidan dalam pelayanan antenatal care sesuai standar.

Tabel 1.5 Distribusi Motivasi dengan kepatuhan Bidan Alumni Politeknik Bhakti Asih Purwakarta angkatan X dan XI terhadap pelayanan antenatal care sesuai standar Hasil analisis menunjukan bahwa ada hubungan antara Motivasi Bidan dengan kepatuhan Dalam pelayanan antenatal care sesuai standar dengan $P$-value 0,000 . Responden yang motivasi tinggi $(67.3 \%)$ dan motivasi rendah (30.8\%). Odds Ratio sebesar 4.6 artinya bidan yang motivasi tinggi mempunyai peluang 4.6 kali lebih besar untuk patuh terhadap pelayanan antenatal care sesuai standar dibandingan dengan bidan yang motivasi rendah.

Motivasi seringkali diartikan dengan istilah dorongan. Setiap tindakan yang dilakukan oleh manusia selalu dimulai dengan motivasi \& Niat. Dengan motivasi petugas akan memiliki semangat tinggi dalam melaksanakan tugas yang dibebankan kepadanya. Tanpa motivasi seorang petugas tidak dapat memetuhi standar dalam bekerja atau bahkan dibawah standar karena apa yang menjadi motif dan motivasinya dalam bekerja tidak terpenuhi.

Hasil penelitian menunjukan persentasi bidan yang memiliki motivasi tinggi lebih banyak di bandingkan dengan motivasi rendah sehingga bidan dengan motivasi tinggi memliliki hubungan terhadap pelayanan antenatal care sesuai standar yang dilakukan oleh Bidan alumni politeknik Bhakti Asih Purwakarta angkatan X dan XI. Dari penelitian yang dilakukan oleh (Sharma et al., 2011) kepatuhan yang rendah dipengaruhi oleh motivasi yang rendah. Tidak ada dorongan akan mempengaruhi perilaku kepatuhan petugas sehingga dorongan dari teman sejawat akan meningkatkan kepatuhan petugas.

\section{KESIMPULAN}

1. Hasil penelitian menunjukan bahwa ada hubungan antara pendidikan bidan dengan kepatuhan terhadap pelayanan antenatal care sesuai standar dengan $P$-value 0,028 .

2. Hasil penelitian menunjukan adanya hubungan pelatihan dengan kepatuhan terhadap pelayanan antenatal care sesuai standar dengan $P$-value 0,034 .

3. Hasil penelitian menunjukan tidak ada hubungan antara supervisi dengan kepatuhan bidan terhadap pelayanan antenatal care sesuai standar dengan $P$-value 0,502

4. Hasil penelitian menunjukan persentasi bidan yang memiliki motivasi tinggi lebih banyak di bandingkan dengan motivasi rendah sehingga bidan dengan motivasi tinggi memiliki hubungan terhadap pelayanan antenatal care sesuai standar dengan P-value 0,000 . 


\section{BIBLIOGRAPHY}

Afriani, E. (2012). Hubungan Motivasi, Supervisi, dan Faktor Lainnya dengan Kepatuhan Bidan Menerapkan Standar Pelayanan Antenatal di Kota Padangsidimpuan Tahun 2012 (Skripsi). Jakarta: Universitas Indonesia.

Bukhari, F. A. (2011). A Hierarchical Evolutionary Algorithmic Design (HEAD) system for generating and evolving building design models. Queensland University of Technology.

Gunawan, S., Walton, N. Y., \& Treiman, D. M. (1990). High-performance liquid chromatographic determination of selected amino acids in rat brain by precolumn derivatization with phenylisothiocyanate. Journal of Chromatography A, 503, 177187.

Notoatmodjo, S. (2012). Promosi kesehatan dan perilaku kesehatan. Jakarta: Rineka Cipta, 45-62.

Nurbaeti, Y. (2000). Faktor yang Berhubungan dengan Kepatuhan Petugas terhadap Standar Antenatal Care (ANC) di 6 Puskesmas Pelaksana QA di Kabupaten Bekasi Provinsi Jawa Barat. Fakultas Kesehatan Masyarakat UI Jakarta (Tesis).

Prual, A., Toure, A., Huguet, D., \& Laurent, Y. (2000). The quality of risk factor screening during antenatal consultations in Niger. Health Policy and Planning, 15(1), 11-16.

Rahayu, S. (2011). Faktor Psikologi Dan Organisasi Yang Mempengaruhi Kepatuhan Bidan Desa Terhadap Standar Operasional $7 t$ Pada Pelayanan Antenatal Di Kabupaten Semarang Tahun 2011. Universitas Diponegoro.

Setyowati, A. D. (2009). Beberapa Faktor yang Berhubungan dengan Kepatuhan Perawat dalam Pengumpulan Anggka Kredit untuk Kenaikan Pangkat di Kabupaten Banjarnegara tahun 2009. Diponegoro University.

Sharma, N., Singh, N. K., \& Bhadwal, M. S. (2011). Relationship of somatic cell count and mastitis: An overview. Asian-Australasian Journal of Animal Sciences, 24(3), $429-438$.

(C) 2021 by the authors. Submitted for possible open access publication under the terms and conditions of the Creative Commons Attribution (CC BY $\quad$ ND) license (https://creativecommons.org/licenses/by/3.0/). 